\title{
Methods of generating human pluripotent stem cell-derived alveolar stem cells and their expansion
}

Shimpei Gotoh ( $\sim$ a0009650@kuhp.kyoto-u.ac.jp )

Gotoh's group, Kyoto University

Yuki Yamamoto

Gotoh's group, Kyoto University

Method Article

Keywords: Pluripotent stem cell, alveolar epithelial cell differentiation, long-term culture, organoid

Posted Date: October 3rd, 2017

DOI: https://doi.org/10.1038/protex.2017.097

License: (c) (i) This work is licensed under a Creative Commons Attribution 4.0 International License. Read Full License 


\section{Abstract}

Although the methods of generating human lung epithelial cells have been studied ${ }^{1-8}$, there have been no reports for efficient generation and expanding alveolar type II cells as tissue stem cells producing pulmonary surfactant. Here we show a novel protocol for efficient generation and long-term expansion of SFTPC ${ }^{+}$alveolar stem cells derived from human pluripotent stem cells $\backslash$ (hPSCs). Although we previously developed a method of 3D co-culture differentiation of $\mathrm{CPM}^{+}$cells with fetal human lung fibroblasts to induce alveolar stem cells $^{6}$, the induction efficiency had been $<20 \%$ and it was difficult to maintain the alveolar stem cells for a long term. In this protocol, we added a step for preconditioning NKX2.1 $1^{+}$cells toward alveolar stem cell differentiation and established a method of their passages. Moreover, we also developed a method of fibroblast-free induction of SFTPC ${ }^{+}$alveolar stem cells in order to avoid the usage of human fetal lung fibroblasts. This protocol accompanies Yamamoto et al $\backslash(10.1038 / \mathrm{nmmeth} .4448)$, Nature Methods, published online October 2 , 2017. ${ }^{* *}$ Corrections have been made to this protocol since it was published ${ }^{* \star}$ In the version of this protocol initially published, the concentration of 8-Br-cAMP, 3-isobutyl-1-methylxanthine and KGF in "Alveolarization medium" described in "E-2" section of "Procedure" was incorrectly typed; 8-Br-cAMP \(it was $100 \mathrm{nM}$; the correct units are $\mu \mathrm{M}$ ), 3-isobutyl-1-methylxanthine \(it was $100 \mathrm{nM}$; the correct units are $\mu \mathrm{M}$ ) and KGF $\backslash$ (it was $100 \mathrm{ng} / \mathrm{ml}$; the correct concentration is $10 \mathrm{ng} / \mathrm{ml}$ ).

\section{Introduction}

Alveolar epithelial type II \(AT2) cells are tissue stem cells contributing to alveolar homeostasis by self-renewing, differentiating into alveolar type I $\backslash$ (AT1) cells and producing pulmonary surfactant ${ }^{9}$. However, AT2 cells have been known to lose their specific properties such as the expression of SFTPC immediately after starting conventional two-dimensional culture ${ }^{10}$. Despite the high demand for research use of human alveolar epithelial cells, it has been difficult to obtain primary AT2 cells from clinical lung tissues or achieve efficient induction and expansion of hPSC-derived AT2 cells ${ }^{4-6,8}$. In this protocol, we established a 35-day protocol for induction of alveolar stem cells by forming alveolar organoids $\backslash$ (AOs) involving human fetal lung fibroblasts $\backslash($ fibroblast-dependent AOs, FD-AOs) using preconditioned CPM ${ }^{\text {high }}$ alveolar progenitor cells derived from hPSCs. This protocol was highly reproducible in multiple hPSC lines and adaptive to long-term expansion of alveolar stem cell maintaining their properties as alveolar stem cells. Finally, we alternatively developed a 28-day protocol for generation of AOs without using human fetal lung fibroblasts $\backslash$ (fibroblasts-free AOs, FF-AOs). Our methods provide a versatile platform of studying human alveoli in vitro for researchers.

\section{Reagents}

PBS \(Nacalai tesque, 14249-24) RPMI1640 \(Nacalai tesque, 30264-56) DMEM/F12 plus Glutamax \(ThermoFisher, 10565-042) DMEM with high glucose $\backslash$ (Nacalai tesque, 08459-64) Ham/F12 \(Wako, 087-08355) Primate ES medium \(ReproCELL, RCHEMD001) Essential 8 medium \(ThermoFisher, A1517001) Fetal bovine serum \(FBS) \(ThermoFisher, heat inactivated) Knockout Serum Replacement $\backslash$

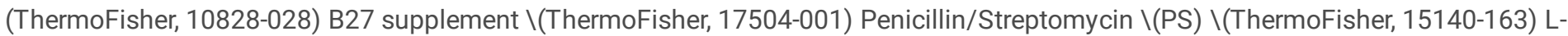
glutamine \(ThermoFisher, 25030-164) GlutaMAX supplement $\backslash($ ThermoFisher, 35050-061) NEAA \(ThermoFisher, 11140-050) 2mercaptoethanol $55 \mathrm{mM} \backslash$ (ThermoFisher, 21985-023) Monothioglycerol $50 \mathrm{mM} \backslash($ Wako, 195-15791) L-ascorbic acid $\backslash($ Wako, 012-04802) 7.5\% Bovine Serum Albumin \(BSA) \(ThermoFisher, 15260-037) HEPES 1M solution \(Sigma-Aldrich, H0887) ITS premix \(Corning, 354351) Human recombinant bFGF \(DS Pharma Biomedical, KHFGF001) Human recombinant Activin A \(Peprotech, 120-14) Human recombinant Noggin \(HumanZyme, HZ-1085) Human recombinant BMP4 \(HumanZyme, HZ-1148) Human recombinant KGF \(Prospec, CYT-219) Human recombinant FGF10 \(Wako, 060-04401) Sodium butyrate $\backslash(N a B) \backslash(W a k o, 193-015122)$ NOTE: Prepare NaB stock solution as $500 \mathrm{mM}$ in PBS \(Store at $\left.-20^{\circ} \mathrm{C}\right)$. CaCl2 \(Wako, 036-19731) NOTE: Prepare $\mathrm{CaCl} 2$ stock solution as $0.1 \mathrm{M}$ in distilled water $\backslash$ (Store at $4{ }^{\circ} \mathrm{C}$ ) CHIR99021 \(Axon Medchem, Axon1386) SB431542 \(Stem RD, SB-050) All-trans retinoic acid \(ATRA) \(Sigma-Aldrich, R2625) DAPT \(Wako, 049-33583) Dexamethasone \(Sigma-Aldrich, D4902) Br-8-cAMP \(Biolog, B007-500) IBMX \(Wako, 095-03413) Y27632 \(LC Laboratories, Y5301) Gelatin \(Sigma-Aldrich, G1890-100G) Geltrex \(ThermoFisher, A1413202) NOTE: Stock solution is made by adding $5 \mathrm{ml}$ of Geltrex into $500 \mathrm{ml}$ of DMEM $\backslash\left(\right.$ Store at $4{ }^{\circ} \mathrm{C}$ ) Matrigel growth factor reduced $\backslash($ Corning, 354230) Collagenase IV $\backslash$ (ThermoFisher, 17104-019) NOTE: Prepare collagenase IV stock solution as $1 \mathrm{mg} / \mathrm{ml}$ in distilled water $\backslash\left(\right.$ Store at $\left.-20{ }^{\circ} \mathrm{C}\right)$ Accutase $\backslash$ (Innovative Cell Technologies, AT104-500) 2.5\% Trypsin \(ThermoFisher, 15090-046) 0.25\% Trypsin/EDTA \(ThermoFisher, 25200-072) EDTA \(Dojindo, 345-01865) NOTE: Prepare ETDA stock solution as $500 \mathrm{mM} \backslash$ (Autoclave and store at room temperature) and dilute in PBS to $0.5 \mathrm{mM} \backslash\left(\right.$ Store at $4{ }^{\circ} \mathrm{C}$ ) Mouse anti-human CPM \(Leica Microsystems, NCL-CPMm or Abcam, ab49278, clone 1C2) Alexa 647conjugated anti-mouse IgG \(ThermoFisher, A-31571) APC-conjugated mouse anti-human EpCAM \(Miltenyi Biotec, 130-091-254, clone HEA-125) Propidium iodide $\backslash(\mathrm{PI}) \backslash($ Nacalai tesque, 29037-76) NOTE: Prepare PI stock solution as $1 \mathrm{mg} / \mathrm{ml}$ in distilled water $\backslash($ Store at 4 $\left.{ }^{\circ} \mathrm{C}\right)$. 


\section{Equipment}

Filtered tips $\backslash$ (Gilson, P-20, P-200, and P-1000) Disposable pipettes $\backslash(2,5,10,25$ and $50 \mathrm{ml})$ Sterilized conical tubes $\backslash(15 \mathrm{ml}$ and $50 \mathrm{ml})$ Sterilized cell culture dishes $\backslash(6-\mathrm{cm}$ and $10-\mathrm{cm})$ Cell scraper $\backslash(I W A K I, 9000-220)$ Sterilized 6-well cell culture plates $\backslash(G r e i n e r, 657160)$ Sterilized 12-well cell culture plates \(Corning, 3513) Non-adherent 96-well cell culture plate \(Kuraray, SQ 200100 NA) Sterilized Eppendorf tubes $\backslash(1.5 \mathrm{ml})$ Sterilized cell strainers $\backslash(40 \mu \mathrm{m})$ for $50 \mathrm{ml}$ tubes $\backslash($ Greiner, 542040$)$ Cell Culture Insert $0.4 \mu \mathrm{m}$ pore size for 12 well plate $\backslash$ (Corning, 353180) Test tubes with cell strainer snap cap $\backslash($ Falcon, 352235) Round-bottom polypropylene tubes $\backslash($ Falcon, 352063) Sterilized forceps Sterilized disposable scalpels Countess \(ThermoFisher) IX-81 \(Olympus) FACS Aria II or Aria III \(BD Biosciences) Thermostat bath Icebox $5 \% \mathrm{CO} 2$ incubators for $37^{\circ} \mathrm{C}$ Biological safety cabinets $\backslash($ Class II, type A2)

\section{Procedure}

A. Maintenance of human PSCs on feeder cells. B. Maintenance of human PSCs without feeder cells. C. Induction and preconditioning of human PSC-derived NKX2-1+ lung progenitor cells toward alveolar stem cells. D. Isolation of CPM ${ }^{\text {high }}$ progenitor cells after CFKD treatment E. Induction of alveolar stem cells WITH fibroblasts E-1. Preparation of fibroblasts $\backslash$ (a week before isolating CPMhigh progenitor cells) E-2. Coculture of CPM high progenitor cells with fibroblasts by forming organoids E-3. Passaging of human PSC-derived alveolar stem cells. F. Induction of alveolar stem cells WITHOUT fibroblasts A. Maintenance of human PSCs on feeder cells. Preparation . Prepare feeder medium consisting of DMEM $500 \mathrm{ml}$, FBS $38.2 \mathrm{ml} \backslash(7 \%)$, L-glutamine $5.5 \mathrm{ml} \backslash(2 \mathrm{mM})$ and penicillin and streptomycin 2.7 $\mathrm{ml}$. Store at $4{ }^{\circ} \mathrm{C}$. P Prepare ES medium by adding bFGF to primate ES cell medium $\backslash$ (ReproCELL) $\backslash\left(4 \mathrm{ng} / \mathrm{ml}\right.$ of bFGF). Store at $4{ }^{\circ} \mathrm{C}$ and use within two weeks after adding bFGF. · Prepare CTK solution \(Fujioka T, et al. Int J Dev Biol. 2004) for passaging the cells consisting of $2.5 \%$ Trypsin $5 \mathrm{ml}$, collagenase IV stock solution $\backslash(1 \mathrm{mg} / \mathrm{ml}) 5 \mathrm{ml}, 0.1 \mathrm{M} \mathrm{CaCl} 2$ stock solution $0.5 \mathrm{ml}, \mathrm{KSR} 10 \mathrm{ml}$, and sterilized water 30 $\mathrm{ml}$. Store at $-20^{\circ} \mathrm{C}$. . On day -2 or -1 , warm the feeder medium at $37^{\circ} \mathrm{C}$. Prepare dishes coated with $0.1 \%$ gelatin solution 30 minutes at 37 ${ }^{\circ} \mathrm{C}$ in a $\mathrm{CO} 2$ incubator before seeding feeder cells. Prepare required $10-\mathrm{cm}$ dish coated with $5 \mathrm{ml}$ of $0.1 \%$ gelatin at least $>30$ minutes before step 2. On day 0 , warm ES medium at $37^{\circ} \mathrm{C}$ before seeding human pluripotent stem cells $\backslash$ (PSCs). Before passaging the cells, warm CTK solution at $37^{\circ} \mathrm{C}$. Procedure 1 . Thaw a stock vial of STO feeder cells with prewarmed feeder medium $\backslash$ (day -2 or -1$) 2$. Seed mitomycin-treated STO feeder cells \(ECACC, EC07032801-F0) on the gelatin-coated tissue-culture dishes $\backslash(1.5 \times 106$ cells per 10-cm dish). 3. Thaw a stock vial of human PSCs with prewarmed ES medium. CAUTION: This step should be done quickly, but gently. If not, viability of the cell will decrease. 4. Centrifuge the cells in $800 \mathrm{rpm}$ at $20^{\circ} \mathrm{C}$ for 5 minutes. 5 . Resuspend the cells in ES medium and seed on the culture dishes coated with feeder cells. Start medium change two days post-seeding. NOTE: If the viability of the cells were low, supplementation of Y27632 $(10 \mu \mathrm{M})$ will improve the viability of the cells. 6. Change the medium every day. 7. Passage the cells when the cells become $80-90 \%$ confluent in culture. Prepare feeder cells 1 or 2 days before passage as described in Step $1-28$. Discard the medium and wash the dishes twice with PBS $\backslash(5 \mathrm{ml} / 6-\mathrm{cm}$ or $10 \mathrm{ml} / 10-\mathrm{cm}$ dish). 9. Add CTK solution $\backslash(2 \mathrm{ml} / 10-\mathrm{cm}$ dish or $0.8 \mathrm{ml} / 6-$ $\mathrm{cm}$ dish) and incubate until detachment of feeder cells at $37^{\circ} \mathrm{C}$. CAUTION: Incubate PSCs for $1-3$ minutes. Longer incubation might make the PSCs detach from the dish. 10. Discard CTK solution and wash twice with PBS gently. CAUTION: Wash carefully, or PSCs will be detached. 11. Detach the remaining cells with a disposable cell scraper. 12. Discard the medium in the dishes of feeder cells prepared in Step 7. 13. Pipette gently several times and collect the cell suspension. 14. Sub-culture the cell suspension on feeder cells prepared in Step 12. B. Maintenance of human PSCs without feeder cells. Preparation - Warm Essential 8 medium at $37^{\circ} \mathrm{C}$. B Before passaging the cells, warm $0.5 \mathrm{mM}$ EDTA/PBS at $37^{\circ} \mathrm{C}$. P Prepare dishes coated with Geltrex stock solution at least $>2$ hour before Step 3 and 11. Procedure 1. Thaw a stock vial of human PSCs with prewarmed Essential 8 medium. CAUTION: This step should be done quickly, but gently. The viability of the cell will decrease. 2. Centrifuge the cells in $900 \mathrm{rpm}$ at $20^{\circ} \mathrm{C}$ for 5 minutes. 3. Resuspend the cells in Essential 8 medium and plate on the coated dishes. NOTE: If the viability of the cells were low, supplementation of $\mathrm{Y} 27632 \backslash(10 \mu \mathrm{M})$ will improve the viability of the cells. 4. Change the medium every day. 5. Passage the cells when the cells become $90 \%$ confluent in culture. Add Y27632 $\backslash(10 \mu \mathrm{M})$ at least $>1$ hour before passage. 6 . Discard the medium and wash the dishes twice with PBS $\backslash(5 \mathrm{ml} / 6-\mathrm{cm}$ or $10 \mathrm{ml} / 10-\mathrm{cm}$ dish). 7. Add prewarmed $0.5 \mathrm{mM}$ EDTA/PBS $\backslash\left(4 \mathrm{ml} / 6-\mathrm{cm}\right.$ or $10 \mathrm{ml} / 10-\mathrm{cm}$ dish) and incubate for 5 minutes at $37^{\circ} \mathrm{C}$ in a $5 \% \mathrm{CO} 2$ incubator. NOTE: After incubation with $0.5 \mathrm{mM}$ EDTA/PBS, the cells become round and separated. If these changes are not observed, additional 2-minute incubation is recommended. 8. Discard 0.5 mM EDTA/PBS carefully and add Essential 8 medium. 9. Pipette gently several times and collect the cell suspension to a tube. TIPS: DO NOT make single-cell suspension not to decrease the cell viability. 10. Sub-culture the cell suspension on Geltrex-coated dishes. NOTE: Split 1:3 in passing the cells in most cases. C. Induction and preconditioning of human PSC-derived NKX2-1 lung progenitor cells toward alveolar stem cells. Preparation - The following media should be prepared before use. CTK solution as described in Section A. RES medium \(day 0): DMEM/F12 500 ml, KSR 129 ml, Lglutamine $6.5 \mathrm{ml}$, NEAA $6.5 \mathrm{ml}$, 2-meraptoethanol $1.3 \mathrm{ml}$, Penicillin/Streptomycin $3.2 \mathrm{ml}$ supplemented by bFGF $\backslash(5 \mathrm{ng} / \mathrm{ml})$ and Y27632 \} $(10 \mu \mathrm{M})$. NOTE: Use RES medium within two weeks. Endoderm induction medium $\backslash($ day 0,2 and 4): RPMI1640 medium supplemented by

Page 3/6 
human Activin A $\backslash(100 \mathrm{ng} / \mathrm{ml})$, CHIR99021 $\backslash(1 \mu \mathrm{M})$, B27 supplement $\backslash(2 \%)$ and penicillin/streptomycin $\backslash(50 \mathrm{U} / \mathrm{ml})$. NOTE: Mix on the day of use. Anteriorization medium \(day 6 and 8): DMEM/F12 plus Glutamax medium, B27 supplement $\backslash(2 \%)$, penicillin/streptomycin $\backslash(50$ $\mathrm{U} / \mathrm{ml})$, L-ascorbic acid $\backslash(0.05 \mathrm{mg} / \mathrm{ml})$ and monothioglycerol $\backslash(0.4 \mathrm{mM})$, human Noggin $\backslash(100 \mathrm{ng} / \mathrm{ml})$, and SB431542 $\backslash(10 \mu M)$. NOTE: Add human Noggin and SB431542 on the day of use. Ventralization medium \(day 10 and 12): DMEM/F12 plus Glutamax medium, B27 supplement $\backslash(2 \%)$, penicillin/streptomycin $\backslash(50 \mathrm{U} / \mathrm{ml})$, L-ascorbic acid $\backslash(0.05 \mathrm{mg} / \mathrm{ml})$ and monothioglycerol $\backslash(0.4 \mathrm{mM})$, human BMP4 $\backslash$ $(20 \mathrm{ng} / \mathrm{ml})$ and the following doses of all-trans retinoic acid \(ATRA) and CHIR99021. NOTE: Add human BMP4, ATRA and CHIR99021 on the day of use. NOTE: Optimized concentration of ATRA and CHIR99021 in each PSC line should be determined. Each combination of ATRA/CHIR99021 is $0.5 \mu \mathrm{M} / 3.5 \mu \mathrm{M} \backslash(\mathrm{H} 9 \mathrm{hESCs}$ and 585A1 hiPSCs), $0.05 \mu \mathrm{M} / 3.0 \mu \mathrm{M} \backslash(201 \mathrm{~B} 7$ and B2-3 hiPSCs), $1.0 \mu \mathrm{M} / 2.5 \mu \mathrm{M} \backslash$ (604A1 and 648A1 hiPSCs) and $0.1 \mu \mathrm{M} / 2.5 \mu \mathrm{M} \backslash(409 \mathrm{~B} 2 \mathrm{hiPSCs})$. CFKD preconditioning medium $\backslash($ day 14, 16, 18 and 20): DMEM/F12 plus Glutamax medium, B27 supplement $\backslash(2 \%)$, penicillin/streptomycin $\backslash(50 \mathrm{U} / \mathrm{ml})$, L-ascorbic acid $\backslash(0.05 \mathrm{mg} / \mathrm{ml})$ and monothioglycerol $\backslash(0.4 \mathrm{mM})$, human FGF10 $\backslash(10 \mathrm{ng} / \mathrm{ml})$, human KGF $\backslash(10 \mathrm{ng} / \mathrm{ml})$, CHIR99021 $\backslash(3 \mu \mathrm{M})$ and DAPT $\backslash(20 \mu \mathrm{M})$. NOTE: Add human KGF, FGF10, CHIR99021 and DAPT on the day of use. W Warm PBS, Accutase, \(if your PSCs are feeder-dependent) CTK solution, before starting induction. ' For induction of feeder-dependent PSCs, prepare a 10-cm dish coated with $5 \mathrm{ml}$ of $0.1 \%$ gelatin at least $>30$ minutes before step 8. - Prepare a 6-well plate coated with $1 \mathrm{ml}$ of Geltrex stock solution at least $>2$ hour before step 12. Procedure 1. Add Y27632 \(10 $\mu \mathrm{M})$ to $80-90 \%$ confluent PSCs at least $>1$ hour before step 2. 2. Discard the medium and wash the dishes twice with PBS $\backslash(5 \mathrm{ml} / 6-\mathrm{cm}$ or $10 \mathrm{ml} / 10-\mathrm{cm}$ dish). 3. \(For feeder-dependent PSCs) Add CTK solution $\backslash(2 \mathrm{ml} / 10-\mathrm{cm}$ dish or $0.8 \mathrm{ml} / 6-\mathrm{cm}$ dish) and incubate until detachment of feeder cells at $37^{\circ} \mathrm{C}$. CAUTION: Incubate PSCs for $1-3$ minutes. Longer incubation might make the PSCs detach from the dish. 4. \(For feeder-dependent PSCs) Discard CTK solution and wash twice with PBS gently. CAUTION: Wash carefully, or PSCs will be detached. 5. Add Accutase $\backslash(2 \mathrm{ml} / 10-\mathrm{cm}$ or $0.8 \mathrm{ml} / 6-\mathrm{cm}$ dish $)$ and incubate for 20 minutes at $37^{\circ} \mathrm{C}$ in a $5 \% \mathrm{CO} 2$ incubator. 6. Add RES medium $\backslash(4 \mathrm{ml} / 10-\mathrm{cm}$ or $1.6 \mathrm{ml} / 6-\mathrm{cm}$ dish) and repeat pipetting gently using P-1000 tip for making single-cell suspension. TIPS: This step for making single-cell suspension is critical for successful induction. 7. Centrifuge the cell suspension in $800 \mathrm{rpm}, 20^{\circ} \mathrm{C}$ for 5 minutes, aspirate the supernatant, and resuspended in $10 \mathrm{ml}$ of RES medium \(See Preparation). 8. \(For feeder-dependent PSCs) Plate the resuspended cells on a gelatin-coated dish after discarding gelatin \(See Preparation). 9. \(For feeder-dependent PSCs) Swing the dish gently several times and collect the cell suspension to a tube. 10. Count the number of the cells. For endoderm differentiation, 1.375 $\times 10^{5} \mathrm{cells} / \mathrm{cm}^{2}$ for feeder-free PSCs or $1.1 \times 10^{5} \mathrm{cells} / \mathrm{cm}^{2}$ for feeder-dependent PSCs are optimal. Transfer the required amount of the cell suspension to another $15 \mathrm{ml}$ tube. TIPS: Repeat cell count twice. Accurate cell counting is important for successful induction of definitive endoderm cells. 11. Centrifuge the cell suspension at $800 \mathrm{rpm}$ for 5 minutes at $20^{\circ} \mathrm{C}$ and carefully discard the supernatant. 12 . Resuspend the cells in $2 \mathrm{ml} /$ well $\backslash(6-w e l l ~ p l a t e)$ of endoderm induction medium $\backslash($ See Preparation) supplemented by Y27632 \(10 $\mu \mathrm{M})$ and seed the cells on the Geltrex-coated 6-well plate \(See Preparation). NOTE: Do not add NaB on day 0, or the cells will die. 13. Add $1 \mu$ l / well of $\mathrm{NaB}$ stock solution $\backslash(0.25 \mathrm{mM}) 24$ hours after seeding the cells $\backslash$ (day 1$)$. 14. Replace the endoderm induction medium on day 2 and day 4. 15. On day 6, discard the endoderm induction medium and wash twice with $2 \mathrm{ml} /$ well of prewarmed PBS. CAUTION: Wash quickly with prewarmed PBS. Longer washing time or using cold PBS in this step will cause the detachment of the cells in subsequent steps. 16. Add $2 \mathrm{ml} /$ well of anteriorization medium and change the medium on day 8. 17. On day 10, discard the medium and wash twice with $2 \mathrm{ml} /$ well of prewarmed PBS. CAUTION: Wash quickly with warmed PBS. Longer washing time or using cold PBS in this step will cause the detachment of the cells in subsequent steps. 18. Add $2 \mathrm{ml} /$ well of ventralization medium and change the medium on day 12. 19. On day 14 , replace to $2 \mathrm{ml} /$ well of CFKD preconditioning medium. 20 . Change the CFKD preconditioning medium on day 16,18 , and 20. On day 21, isolate CPM ${ }^{\text {high }}$ progenitor cells as described in Section D. E. Induction of alveolar stem cells WITH fibroblasts E-1. Preparation of fibroblasts $\backslash$ (a week before isolating $\mathrm{CPM}^{\text {high }}$ progenitor cells) Preparation Fibroblast culture medium: DMEM $500 \mathrm{ml}$, FBS $55 \mathrm{ml} \backslash(10 \%)$ and penicillin/streptomycin $\backslash(50 \mathrm{U} / \mathrm{ml})$ Procedure 1 . Thaw a stock vial containing $1.0 \times 10^{6}$ cells of fibroblasts with $10 \mathrm{ml}$ of prewarmed $2 \%$ FBS / DMEM. 2. Centrifuge the cell suspension at $900 \mathrm{rpm}$ for 5 minutes at $20^{\circ} \mathrm{C}$. 3. Discard the supernatant and resuspend the cells in $6 \mathrm{ml}$ of fibroblast culture medium. 4. Prepare three $10-\mathrm{cm}$ dishes with fibroblast culture medium $\backslash(8 \mathrm{ml} / \mathrm{dish}) .5$. Add $2 \mathrm{ml}$ of the cell suspension to each 10-cm dish prepared in step 4. 6. Change the medium every three days. E-2. Coculture of CPMigh progenitor cells with fibroblasts by forming organoids Preparation - Prepare $0.1 \%$ Trypsin / EDTA consisting of $0.25 \%$ Trypsin / EDTA 20 $\mathrm{ml}$ and PBS $30 \mathrm{ml}$. The following medium should be prepared before use. Alveolarization medium: Ham's F12, dexamethasone $\backslash(50$ nM), 3-Isobutyl-1-methylxanthine $\backslash(\mathrm{IBMX}) \backslash(100 \mu \mathrm{M}), \mathrm{B} 27$ supplement $\backslash(1 \%), \mathrm{BSA} \backslash(0.25 \%), \mathrm{HEPES} \backslash(15 \mathrm{mM}), \mathrm{CaCl} 2 \backslash(0.8 \mathrm{mM})$, ITS premix $\backslash(0.1 \%)$, 8-Br-cAMP $\backslash(100 \mu \mathrm{M})$, human $\mathrm{KGF} \backslash(10 \mathrm{ng} / \mathrm{ml})$, and penicillin/streptomycin $\backslash(50 \mathrm{U} / \mathrm{ml})$ NOTE: Add 8-Br-cAMP and human KGF on the day of use. 'Warm PBS and $0.1 \%$ Trypsin / EDTA. C Cool centrifuge at $4{ }^{\circ} \mathrm{C}$. $\cdot$ Cool $2 \%$ FBS / DMEM at $4{ }^{\circ} \mathrm{C}$. Procedure 1. Add $1.0 \mathrm{ml}$ of the alveolarization medium supplemented with $\mathrm{Y} 27632 \backslash(10 \mu \mathrm{M})$ to each well and attach 12-well cell cultures insert to a 12-well plate. 2. Dissociate the prepared fibroblasts. 2.1. Remove the medium and wash the dishes twice with prewarmed $5 \mathrm{ml}$ of PBS. 2.2. Add $1 \mathrm{ml} / 10-\mathrm{cm}$ dish of prewarmed $0.1 \%$ Trypsin / EDTA and incubate for 5 minutes at $37^{\circ} \mathrm{C}$ in a $5 \% \mathrm{CO} 2$ incubator. 2.3. Add $4 \mathrm{ml}$ of $2 \%$ FBS / DMEM and collect the cell suspension to $15 \mathrm{ml}$ tube. 2.4. After cell count, centrifuge the cell suspension at $900 \mathrm{rpm}$ for 5 
minutes at $20^{\circ} \mathrm{C}$. 2.5. Resuspend the cells in $2 \% \mathrm{FBS} / \mathrm{DMEM} \backslash\left(4.0 \times 10^{6}\right.$ cells $\left./ \mathrm{ml}\right) 3$. Prepare the required volume of mixture of $\mathrm{CPM}^{\text {high }}$ progenitor cells $\backslash\left(1.0 \times 10^{4}\right.$ cells / well $)$ and fibroblasts $\backslash\left(5.0 \times 10^{5}\right.$ cells / well $)$. 4 . Centrifuge the mixture at $900 \mathrm{rpm}$ for 5 minutes at $4{ }^{\circ} \mathrm{C}$. 5. Carefully discard the supernatant and resuspend the mixed cells in required amount of $100 \mu \mathrm{l} /$ well of alveolarization medium supplemented with $\mathrm{Y} 27632 \backslash(10 \mu \mathrm{M})$. 6. Dispense the cell suspension into $100 \mu \mathrm{l}$. 7. Mix the cell suspension with equal volume of Matrigel and seed a total volume of $200 \mu \mathrm{l} /$ sample onto a cell culture insert prepared in step 1. TIPS: In this step, keep Matrigel on ice prior to use. 8. Change the alveolarization medium without Y27632 every 2 days for 14 days. E-3. Passaging of human PSC-derived alveolar stem cells. Preparation - The procedure described in Section E-1 is required a week before passaging. 'Warm required amount $\backslash$ ( $2 \mathrm{ml} /$ well) of $0.1 \%$ Trypsin / EDTA. - Cool centrifuge at $4{ }^{\circ} \mathrm{C}$. $\cdot$ Cool $2 \%$ FBS / DMEM at $4{ }^{\circ} \mathrm{C}$. P Prepare anti-EpCAM antibody solution by mixing $10 \mu \mathrm{l} / 1.0 \times 10^{7}$ cells of APC-conjugated mouse anti-human EpCAM antibody diluted in FACS buffer $\backslash(1: 10)$ on the day of use. Keep away from light and store at $4^{\circ} \mathrm{C}$. Procedure 1. Prepare required number of $15 \mathrm{ml}$ tubes $\backslash$ (a tube / well) with $6 \mathrm{ml}$ of PBS in a tube. 2. Remove cell culture inserts from a 12-well plate using sterilized forceps and tap it on a 6-cm sterilized dish. Fibroblast-dependent AO $\backslash$ (FD-AO) can be easily removed from cell culture inserts. 3. Mince the FD-AO to about $2 \mathrm{~mm} \times 2 \mathrm{~mm} \times 2 \mathrm{~mm}$ using sterilized forceps and a disposable scalpel. CAUTION: Do not mince FD-AO to too small size. It causes damage of the contained cells. 4 . Wash the dishes three times with $2 \mathrm{ml}$ of PBS and collect the fragments in $15 \mathrm{ml}$ tube prepared in step 1. 5. Centrifuge the fragments at 1,000 rpm for 5 minutes at $4{ }^{\circ} \mathrm{C}$. 6. Discard the supernatant and add $2 \mathrm{ml} /$ tube of prewarmed $0.1 \%$ Trypsin / EDTA. 7. Incubate the tubes at $37^{\circ} \mathrm{C}$ for 5 minutes. NOTE: In this step, the fragments of FD-AO will become soft. 8. Reduce the fragment size by pipetting gently 10 times using P-1000 tips. 9. Incubate the tubes at $37^{\circ} \mathrm{C}$ for 5 minutes. 10. Dissociate the fragments by pipetting gently 10 to 15 times using P-1000 tips. NOTE: In this step, the fragments will be almost diminished. 11. Incubate the tubes at $37^{\circ} \mathrm{C}$ for 5 minutes. 12 . Pipetting 10 times again using P1000 tips and neutralize $0.1 \%$ Trypsin / EDTA by adding $8 \mathrm{ml}$ of precooled $2 \%$ FBS / DMEM. CAUTION: Be sure to use precooled $2 \%$ FBS / DMEM. If not, aqueous Matrigel will clot again in the tube involving the cells and spoiled in subsequent steps. 13. Centrifuge the cells at 1,000 rpm for 7 minutes at $4{ }^{\circ} \mathrm{C}$. CAUTION: Precool the centrifuge machine, or Matrigel may clot again in the tube, which can cause the subsequent steps to fail. 14 . Carefully collect the supernatant to another tube and centrifuge at $1,000 \mathrm{rpm}$ for 5 minutes, $4{ }^{\circ} \mathrm{C}$. NOTE: This step will improve the recovery of the cells. CAUTION: Do not aspirate the supernatant adjacent to cell pellets. Occasionally, Matrigel remains in this layer adhering to the cell pellets. 15. Collect the recovered cells in one tube with $5 \mathrm{ml}$ of FACS buffer and count the number of the cells. 16. Centrifuge the cell suspension at 1,000 rpm for 5 minutes at $4{ }^{\circ} \mathrm{C}$ and carefully discard the supernatant. 17 . Incubate in anti-EpCAM antibody solution at $4^{\circ} \mathrm{C}$ for 15 minutes. Keep away from light during incubation. 18. Add $5 \mathrm{ml} /$ tube of FACS buffer, and centrifuge the cell suspension at $900 \mathrm{rpm}$ for 5 minutes at $4{ }^{\circ} \mathrm{C}$. 19. Discard the supernatant and resuspend the cells in $5 \mathrm{ml} /$ tube of FACS buffer. 20. Centrifuge them at $900 \mathrm{rpm}$ for 5 minutes at $4{ }^{\circ} \mathrm{C}$. 21. Discard the supernatant and resuspend the cells in $1 \mathrm{ml} /$ $8.0 \times 10^{6}$ cells of FACS buffer with $1 / 1000$ volume of PI stock solution. 22. Strain the cells through a cell strainer with $40 \mu \mathrm{m}$ mesh. CAUTION: If not, the buffer containing the cells can splash in Step 23 23. Prepare cells for FACS in a round bottom tube capped with a cell strainer. 24. Prepare the collection tubes with $1 \mathrm{ml} /$ tube of FACS buffer for sorted cells. 25. Sort the EpCAM ${ }^{+}$SFTPC ${ }^{+}$cells using FACS Aria II or Aria III. 26. Centrifuge the cells at $1,000 \mathrm{rpm}$ for 10 minutes at $4{ }^{\circ} \mathrm{C}$. 27. Discard the supernatant and resuspend the cells in $500 \mu \mathrm{l}$ of FACS buffer. 28. Repeat the steps described in Section E-2 with replacing $\mathrm{CPM}^{\text {high }}$ progenitor cells by EpCAM ${ }^{+} \mathrm{SFTPC}^{+}$cells. $^{\mathrm{F}}$. Induction of alveolar stem cells WITHOUT fibroblasts Preparation - The following medium should be prepared before use. Fibroblast-free

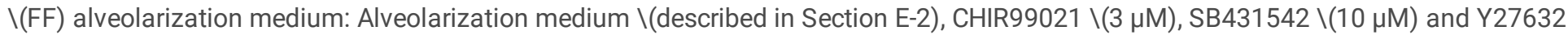
$\backslash(10 \mu \mathrm{M})$. NOTE: Add CHIR99021, SB431542 and Y27632 on the day of use. Procedure 1. Suspend $2.0 \times 10^{5} \mathrm{CPM}^{\text {high }}$ progenitor cells prepared in Section D in $250 \mu \mathrm{l}$ of FF alveolarization medium. 2. Add the cell suspension onto a non-adherent surface 96 -well plate $\backslash$ (Kuraray, SQ 200100 NA). 3. On day 2, collect cell aggregates into $1.5 \mathrm{ml}$ Eppendorf tube by gently pipetting and aspirate using P-1000 tip. 4. Wash the wells with FACS buffer once and collect the remained cell aggregates. 5. Spin down the cell aggregates for 3 minutes using a tabletop personal centrifuge. 6. Remove the supernatant using P-1000 tip. 7. Remove the remained supernatant carefully using P200 tip as possible. CAUTION: Too much remained supernatant can cause the subsequent steps to fail. CAUTION: Remove the supernatant quickly, or the pellet will crumble. 8. Resuspend the cell aggregates in $20 \mu$ of precooled Matrigel and place onto a well of 12-well cell culture plate quickly. CAUTION: Use P-20 tips and precooled Matrigel. If not, Matrigel will rapidly clot inside the tips. 9. Incubate the cell culture plate for 20 minutes at $37^{\circ} \mathrm{C}$ in a $5 \% \mathrm{CO} 2$ incubator. Add $1 \mathrm{ml}$ of FF alveolarization medium and change the medium on day 2,4 and 6 .

\section{Timing}

A. Maintenance of human PSCs on feeder cells. \(30 min) B. Maintenance of human PSCs without feeder cells. \(30 min) C. Induction and preconditioning of human PSC-derived NKX2-1 lung progenitor cells toward alveolar stem cells. $\backslash(2$ hours for induction of definitive endoderm step. $30 \mathrm{~min}$ for changing each medium. 21 days to induce preconditioned NKX2-1+ progenitor cells) D. Isolation of CPM high

Page 5/6 
progenitor cells after CFKD treatment. \(6 hours, normally. It will take more time depending on the numbers of cells that you need) E. Induction of alveolar stem cells WITH fibroblasts E-1. Preparation of fibroblasts $\backslash$ (a week before isolating CPM ${ }^{\text {high }}$ progenitor cells) $\backslash(30$ min) E-2. Coculture of CPM ${ }^{\text {high }}$ progenitor cells with fibroblasts by forming organoids $\backslash(2$ hours) E-3. Passaging of human PSC-derived alveolar stem cells. \(8 hours) F. Induction of alveolar stem cells WITHOUT fibroblasts $\backslash(1$ hour)

\section{Troubleshooting}

http://www.nature.com/protocolexchange/system/uploads/5845/original/Protocol_exchange_ver9_SupTable_submission_YY_SG.docx? 1502353699

\section{Anticipated Results}

http://www.nature.com/protocolexchange/system/uploads/5835/original/Supplementary_Protocol_fig_1_Aug10.pdf?1502376749 http://www.nature.com/protocolexchange/system/uploads/5837/original/Supplementary_Protocol_fig_2_Aug10.pdf?1502353989

\section{References}

1. Green, M. D. et al. Generation of anterior foregut endoderm from human embryonic and induced pluripotent stem cells. Nat. Biotechnol. 29, 267-272 \(2011). 2. Longmire, T. A. et al. Efficient derivation of purified lung and thyroid progenitors from embryonic stem cells. Cell. Stem Cell. 10, 398-411 \(2012). 3. Schmeckebier, S. et al. Keratinocyte growth factor and dexamethasone plus elevated cAMP levels synergistically support pluripotent stem cell differentiation into alveolar epithelial type II cells. Tissue Eng. Part A. 19, 938-951 \(2013). 4. Ghaedi, M. et al. Human iPS cell-derived alveolar epithelium repopulates lung extracellular matrix. J. Clin. Invest. 123, 4950-4962 \(2013) 5. Huang, S. X. et al. Efficient generation of lung and airway epithelial cells from human pluripotent stem cells. Nat. Biotechnol. 32, 84-91 $\backslash(2014)$. 6. Gotoh, S. et al. Generation of alveolar epithelial spheroids via isolated progenitor cells from human pluripotent stem cells. Stem Cell. Reports 3, 394-403 \(2014). 7. Konishi, S. et al. Directed induction of functional multi-ciliated cells in proximal airway epithelial spheroids from human pluripotent stem cells. Stem Cell. Reports 6, 18-25 \(2016). 8. McCauley, K.B. et al. Efficient derivation of functional human airway epithelium from pluripotent stem cells via temporal regulation of Wnt signaling. Cell Stem Cell. 20, 844-857 $\backslash$ (2017). 9. Barkauskas, C. E. et al. Type 2 alveolar cells are stem cells in adult lung. J. Clin. Invest. 123, 3025-3036 \(2013). 10. Dobbs, L. G., Williams, M. C. \& Gonzalez, R. Monoclonal antibodies specific to apical surfaces of rat alveolar type I cells bind to surfaces of cultured, but not freshly isolated, type II cells. Biochim. Biophys. Acta. 970, 146-156 \(1988).

\section{Supplementary Files}

This is a list of supplementary files associated with this preprint. Click to download.

- supplement0.pdf

- supplement0.docx

- supplement0.pdf 